\title{
Pasívna legitimácia pri zásahoch do cti, dôstojnosti a dobrej povesti výrokmi osôb použitých pri informovaní o výkone verejnej moci (1. čast')
}

\author{
Kerecman, P.*
}

KERECMAN, P.: Pasívna legitimácia pri zásahoch do cti, dôstojnosti a dobrej povesti výrokmi osôb použitých pri informovaní o výkone verejnej moci (1. čast'). Právny obzor, 104,2021 , č. 3 , s. $208-228$.

Passive legitimacy in cases of damage to the honour, dignity and good reputation by statements of persons, used for informing about the execution of public power (Part 1). Honour, dignity or reputation can be affected by, among other things, statements made by leading politicians, spokespeople for state institutions or the content of press releases provided to the media when informing them about the exercise of public authority. Since the media, further disseminating this information, are not responsible for its veracity, it is necessary to reliably identify the entity responsible for such effects. Slovak judicial practice assesses actions in these cases under the provisions of the Civil Code on protection of personal rights and concludes that the entity responsible for the effect is not the state, but the state institution responsible for the statement of the natural person, because that person does not act directly on behalf of the state. However, these conclusions were drawn without careful consideration being given to the possibility of judging these claims under the Public Liability Act. When examining this problem, it is also necessary to address the theoretical starting point of the problem, in particular the nature of the liability of the state and state institutions, the requirements for there to arise liability for damages and nonmaterial damage outside the exercise of public authority, the nature and extent of liability for damage and non-material damage in the exercise of public authority, the interrelationships between the rules governing liability in both cases and also the concept of liability for others in the conclusions of legal theory and practice.

Key words: exercise of public authority, personal rights, liability for the actions of a representative, compensation for non-material damage

\section{Na úvod}

Predpokladom úspešného uplatnenia práva na ochranu cti, dôstojnosti fyzickej osoby alebo dobrej povesti právnickej osoby je nie len to, že došlo k zásahu do týchto práv, ktorý je neoprávnený a objektívne spôsobilý privodit' ujmu na týchto právach, ale aj ustálenie subjektu, ktorý je za takýto zásah zodpovedný, teda je nositel'om povinnosti od takéhoto zásahu upustit' a odstránit' jeho následky poskytnutím satisfakcie. Nie vždy je však priamy pôvodca zásahu totožný so subjektom, ktorý je za zásah zodpovedný. Zodpovedným subjektom môže byt' fyzická osoba, právnická osoba ale i štát.

Vyriešenie tejto otázky môže byt' zložité najmä vtedy, ked' do úvahy prichádza viacero zodpovedných subjektov. Tak je tomu aj v prípadoch, ked' k zásahu do cti, dôstojnos-

\footnotetext{
* JUDr. Peter K e r e c m a n, Ústav štátu a práva SAV; advokát.
} 
ti alebo dobrej povesti dôjde obsahom informácií poskytnutých masovým médiám pri informovaní o činnosti štátnych orgánov. Takéto informácie poskytujú totiž médiám konkrétne fyzické osoby, ktoré používa štát alebo jeho orgán, pri plnení svojich úloh. Ide tu nie len o hovorcov jednotlivých štátnych orgánov, ale aj o ústavných činitel'ov (minister, predseda vlády, prezident, verejný ochranca práv a pod.).

Zdanlivo jednoznačné schematické riešenie týchto prípadov spočívajúce v závere, podl'a ktorého samotná fyzická osoba za zásah (ak nejde o exces z plnenia povinností) nezodpovedá a zodpovedným má byt' subjekt, ktorý ju na túto činnost' použil, problém nevyčerpáva. Rozhodovacia prax totiž na otázku, či je v takýchto prípadoch zodpovedným štát alebo jeho orgán (iná právnická osoba zriadená štátom) nedala presvedčivú odpoved' napriek existencii viacerých rozhodnutí Najvyššieho súdu Slovenskej republiky.

Pritom spol'ahlivé vyriešenie tejto otázky je predpokladom reálneho naplnenia základného práva na ochranu cti, dôstojnosti, súkromia a dobrej povesti (čl. 19 Ústavy Slovenskej republiky) poškodenej osoby, pretože nemožno pripustit', aby táto ochrana bola zmarená iba pre nejasné posudzovanie pasívnej vecnej legitimácie v súdnom konaní.

\section{O rôznej povahe zodpovednosti štátu a štátnych inštitúcií}

Štát plní svoje funkcie prostredníctvom rôznych osôb, zložiek či orgánov v rozsahu právnym poriadkom zverenej právomoci a pôsobnosti. Štát sám nielen stanovuje pravidlá a kontroluje ich dodržiavanie, no o svojej činnosti aj informuje. Pri všetkých činnostiach štátu, resp. jeho orgánov, môže dôjst' k pochybeniam. Je to dané predovšetkým tým, že v mene štátu konajú l'udia a tí zo svojej prirodzenej nedokonalosti robia chyby. Hoci v mene štátu koná človek, predpokladá sa, že štát robit’ chyby nemá. ${ }^{1}$

Štát môže mat' v právnych vzt'ahov dvojaké postavenie. Ak vstupuje do právneho vzt’ahu ako subjekt v rovnom postavení s inými účastníkmi tohto vzt’ahu, stáva sa účastníkom vzt’ahov súkromnoprávnych. ${ }^{2}$ Ak je obsahom právneho vzt’ahu výkon štátnej moci, ide o vzt’ah verejnoprávny, v ktorom má štát nadradené (vrchnostenské) postavenie. Štátna moc (ako forma verejnej moci) ${ }^{3}$ je vykonávaná prostredníctvom orgánov zákonodarnej, výkonnej a súdnej moci a môže byt' nimi uplatňovaná iba v súlade s princípom legality, t. j. na základe Ústavy, v jej medziach a v rozsahu a spôsobom, ktorý ustanoví zákon (čl. 2 ods. 2 Ústavy Slovenskej republiky). Účelom zásady „čo nie je dovolené, je zakázané“ je vytvorenie právnej istoty pre subjekty súkromného práva, že štátne orgány nebudú voči nim konat' v rozpore so svojou právomocou a že sa budú správat'

\footnotetext{
${ }^{1}$ KOLBA, J., ŠULÁKOVÁ, M. Nemajetková újma zpiosobená protiprávním výkonem veřejné moci. Praha : Leges, 2014, s. 17.

${ }^{2}$ Rozsudok Najvyššieho súdu Slovenskej republiky sp. zn. 4 Cdo 93/2008 z 30. 9. 2008.

3 Štátna moc je považovaná za podskupinu verejnej moci, za d'alšie bývajú považované verejná moc územnej samosprávy a verejná moc občianskej spoločnosti. K tomu viac KRÁLIK, J. Kontrolná moc systémový prvok verejnej moci vo verejnej správe. In Štát a právo, č. 1/2014, s. 82, cit. podl’a: DRGONEC, J. Ústava Slovenskej republiky. 2. vydanie. Bratislava : Nakladatel'stvo C. H. Beck, 2019, s. 270.
} 
v súlade s právnym poriadkom ${ }^{4}$. Každý občan má (totiž) právo na to, aby sa všetky štátne orgány voči nemu správali len spôsobom, ktorý im dovol'uje ústava a d'alšie zákony. ${ }^{5}$

Pretože štát ako abstraktná entita nemôže vykonávat' svoje úlohy bezprostredne, vytvára si na tento účel osobitné orgány, ktoré zastupujú štát v jeho jednotlivých činnostiach. ${ }^{6}$ Štát realizuje svoje funkcie prostredníctvom štátnych inštitúcii. Sú nimi jednak štátne orgány, ktorých existencia je zakotvená v osobitných predpisoch, jednak rôzne d'alšie štátne organizácie (napr. príspevkové, rozpočtové) zriad’ované bud' priamo zákonom, alebo na jeho základe (vládne organizácie). Štátne orgány na rozdiel od štátnych organizácii sú reprezentantmi, držitel'mi a vykonávatel'mi štátnej moci. ${ }^{7}$ Personálny substrát štátu tvoria osoby, ktoré sú reprezentantmi verejnej moci (ústavní činitelia, resp. verejní funkcionári) ${ }^{8}$ a osoby, ktoré plnia svoje úlohy vo verejnej alebo štátnej službe (štátni zamestnanci) ${ }^{9}$.

Pri výkone štátnej moci konajú štátne orgány priamo v mene štátu a svojím konaním štát zaväzujú. Ostatné funkcie plní štát predovšetkým prostredníctvom iných štátnych inštitúcií. Osobitná úprava (spravidla) stanovuje, že tieto konajú vo vlastnom mene. Štátne inštitúcie sú obvykle právnickými osobami (majú právnu subjektivitu) a svojím konaním v zákonom stanovených prípadoch zaväzujú iba samy seba. Aj niektoré štátne orgány však (popri výkone štátnej moci v mene štátu) plnia aj iné funkcie štátu, pričom v takýchto prípadoch konajú (podl'a osobitných predpisov) vo vlastnom mene a svojím konaním tiež zaväzujú iba samy seba. Štát nemožno zamieňat' s jeho štátnymi orgánmi a štátnymi inštitúciami. Postavenie štátu v právnych vzt’ahoch sa teda rozlišuje aj podl'a toho, či výkon práv a povinností $\mathrm{v}$ danom právnom vzt’ahu realizuje štát sám vo vlastnom mene prostredníctvom svojej organizačnej zložky, alebo ich výkonom na základe právnej úpravy poveril iné subjekty, ktoré výkon práv a povinností realizujú vo vlastnom mene.

V prípade, ak štátne orgány pri výkone verejnej (štátnej) moci konajú v mene štátu, je nositel'om práv a povinností štát, v ktorého mene koná štátny orgán ako jeho organizačná zložka. Ak pri plnení iných funkcií štátu konajú štátne orgány a štátne organizácie (podl'a osobitného predpisu) vo vlastnom mene, je nositel'om práv a povinností štátny orgán (organizácia). Tieto situácie je potrebné dôsledne rozlišovat', lebo od ich správneho rozlíšenia závisí odpoved' na otázku, ktorý subjekt je účastníkom hmotnoprávneho vzt'ahu, a teda bude pasívne vecne legitimovaným v spore z tohto vzt'ahu. Zatial' čo v prvom prípade ním bude štát, za ktorý koná jeho organizačná zložka (štátny orgán), v druhom prípade ním bude štátny orgán alebo štátna organizácia (štátna inštitúcia).

${ }^{4} \mathrm{~K}$ tomu viac DRGONEC, J. Ústava Slovenskej republiky. 2. vydanie. Bratislava : Nakladatel'stvo C. H. Beck, 2019, s. $272-273$.

${ }^{5}$ Ústavný súd Slovenskej republiky, I. ÚS 76/2011. Cit. podl'a DRGONEC, J. Ústava Slovenskej republiky. 2. vydanie. Bratislava : Nakladatel'stvo C. H. Beck, 2019, s. 274

${ }^{6}$ POSLUCH, M., CIBULKA, L'. Štátne právo slovenskej republiky. Bratislava : PF UK, 1994, s. 72.

${ }^{7}$ PRUSÁK, J. Teória práva. Bratislava : PF UK, 1995, s. 74.

${ }^{8}$ Prusák hovorí s ohl’adom na dobu vzniku diela (PRUSÁK, J. Teória práva. Bratislava : PF UK, 1995, s. 74) o verejných činitel'och, terminologicky ale nejde o „,verejného činitel’a“ definovaného v úst. zák. č. 357/2004 Z. z. o ochrane verejného záujmu pri výkone funkcií verejných funkcionárov (čl. 2); viac tomuto pojmu zodpovedá pojem „ústavný činitel““v zmysle zák. č. 120/1993 Z. z. o platových pomeroch ústavných činitel'ov (§1).

${ }^{9}$ K tomu viac napr.: PRUSÁK, J. Teória práva. Bratislava : PF UK, 1995, s. 74 a nasl. 
To platí aj v prípadoch, ked' hmotnoprávnym vzt’ahom je vzt’ah zodpovednostný. Preto za škodu spôsobenú pri výkone verejnej (štátnej) moci je zodpovedným subjektom priamo štát a v ostatných prípadoch (spravidla) štátny orgán (štátna organizácia).

Tieto východiská sú významné aj pre záver o pasívnej vecnej legitimácii žalovaného v súdnom konaní. Vecnou legitimáciou je stav vyplývajúci z hmotného práva, ked’ jedna strana je subjektom hmotnoprávneho oprávnenia, o ktoré v konaní ide, a druhá je subjektom hmotnoprávnej povinnosti. Ak je stranou súdneho konania štát, v žalobe sa označuje uvedením jeho názvu a názvu štátneho orgánu alebo právnickej osoby, ktorá za štát koná (§ 135 ods. 1 CSP); ak je stranou štátny orgán, v žalobe sa označuje uvedením názvu tohto štátneho orgánu ( $\$ 135$ ods. 2 CSP). Kto (v prvom prípade) za štát pred súdom koná, určuje osobitný predpis o konaní za štát (§ 73 CSP). Pritom však označenie orgánu alebo právnickej osoby, ktorá podl’a osobitného predpisu za štát koná, nie je otázkou pasívnej legitimácie žalovaného ${ }^{10}$, a prípadné nesprávne označenie orgánu alebo osoby nie je vadou žaloby ani nedostatkom podmienok konania - je vecou konajúceho súdu zabezpečit', aby za štát konal ten orgán alebo právnická osoba, do ktorého pôsobnosti podl'a osobitného predpisu vec patrí.

Deliktuálnu zodpovednost' štátu (jeho inštitúcií) za škodu a nemajetkovú ujmu v prípadoch, ked' ju spôsobia v súkromnoprávnom vzt'ahu, je potrebné posudzovat' podl'a všeobecnej úpravy deliktuálneho práva (najmä Občiansky zákonník). Zodpovednost' štátu za škodu a nemajetkovú ujmu spôsobenú pri výkone štátnej moci realizovanom v rozpore s princípom legality (najmä s požiadavkou jej výkonu spôsobom ustanoveným zákonom) je zodpovednost'ou upravenou v osobitnom predpise verejného práva (najmä zák. č. 514/2003 Z. z. o zodpovednosti za škodu spôsobenú pri výkone verejnej moci d'alej len zák. č. 514/2003 Z. z.). Niektoré špecifické prípady zodpovednosti za škodu a nemajetkovú ujmu sú však upravené aj v d’alších osobitných prameňoch verejného práva, ktoré spravidla určujú i zodpovedný subjekt jeho konkrétnym pomenovaním (štát alebo určitú štátnu inštitúciu) ${ }^{11}$.

\section{Zásahy do cti, dôstojnosti alebo dobrej povesti výrokmi štátom použitých osôb v slovenskej rozhodovacej praxi}

Najvyšší súd Slovenskej republiky sa pasívnou vecnou legitimáciou v konaní o žalobe na ochranu pred zásahom do cti, dôstojnosti alebo dobrej povesti, do ktorých bolo zasiahnuté výrokmi štátom použitých osôb pri informovaní o činnosti štátu (štátnych orgánov), zaoberal v niekol'kých prípadoch. Takéto žaloby posudzoval podl'a ustanovení o ochrane osobnosti v zák. č. 40/1964 Zb. Občiansky zákonník (d’alej len OZ) a za pasívne vecne legitimovaný subjekt považoval štátny orgán, a nie štát. Tento záver označil za ustálenú súdnu prax.

${ }^{10}$ Rozsudok Najvyššieho súdu Československej socialistickej republiky, sp. zn. 6 Cz 192/66 z 14. 12. 1966 (R 48/1967).

${ }^{11}$ Napr. $§ 78$ ods. 5 zák. č. 171/1993 Z. z. o Policajnom zbore. 


\section{a/ Zodpovednost' za výroky hovorcu Prezídia Policajného zboru (R 75/2015)}

V prvej z týchto vecí informoval hovorca Prezídia Policajného zboru médiá na tlačovej besede o policajnej akcii, pri ktorej bol zadržaný a obvinený i žalobca. Ten pestoval certifikované technické konope, ktoré bolo v tom čase legálnou plodinou. Policajti konope zožali, no predbežná expertíza preukázala, že plodina žalobcu tzv. THC neobsahovala, preto žalobcu policajti ešte v rovnaký deň prepustili a ospravedlnili sa mu. V policajnej správe bol však žalobca označený ako drogový díler a hovorca Prezídia Policajného zboru na tlačovej besede štyri dni po prepustení žalobcu informoval médiá, že zo zdržaného množstva rastlín sa dalo vyrobit' 21200 obvyklých dávok drogy, hoci, ako vyplynulo z policajnej expertízy, droga sa z neho vyrobit' nedala. Neskôr vypracovaný znalecky posudok potvrdil závery expertízy.

Žalobca sa žalobou domáhal ospravedlnenia a náhrady nemajetkovej ujmy v peniazoch za neoprávnený zásah do jeho cti, ku ktorému malo dôjst’ týmito výrokmi hovorcu Prezídia Policajného zboru na tlačovej besede. Za žalovaného označil štát (Slovenskú republiku v zastúpení Ministerstvom vnútra Slovenskej republiky).

Prvostupňový súd žalobe vyhovel. Vec posúdil podl'a $§ 11-13 \mathrm{OZ}$, nestotožnil sa s námietkou žalovanej, že pasívne legitimované má byt' Ministerstvo vnútra Slovenskej republiky a nie Slovenská republika, s odôvodnením, že ide o konanie orgánov zastupujúcich štát počas trestného konania. Žalovaný v odvolaní argumentoval tým, že hovorca Prezídia Policajného zboru bol v štátnej službe v služobnom úrade ministerstva vnútra, ktoré ako služobný úrad zodpovedá za výkon služobného pomeru policajta a táto zodpovednost’ nie je daná štátu. Odvolací súd rozhodnutie okresného súdu zmenil a žalobu zamietol pre nedostatok pasívnej vecnej legitimácie žalovaného. Aj odvolací súd vec posudzoval podl'a $\S 11$ - $13 \mathrm{OZ}$, no vychádzal z toho, že k porušeniu práv a povinností nedošlo konaním Slovenskej republiky, ale člena Policajného zboru počas výkonu štátnej služby príslušníka Policajného zboru, v dôsledku čoho je daná zodpovednost' Ministerstva vnútra Slovenskej republiky, ktoré riadi Policajný zbor. Hoci hovorca poskytoval informácie o činnosti polície médiám v rámci svojej zamestnaneckej činnosti, nešlo o priame zastupovanie štátu, a štát preto nie je nositel'om zodpovednosti za konanie hovorcu - za jeho činnost' zodpovedá ministerstvo vnútra ako samostatný subjekt práv a povinností stanovených zákonom.

Najvyšší súd Slovenskej republiky dovolanie žalobcu zamietol a uzavrel, že: „Vkonaní o ochranu osobnosti fyzickej osoby, do ktorej bolo zasiahnuté nepravdivou informáciou poskytnutou médiám hovorcom ústredného orgánu štátnej správy, je pasívne vecne legitimovaný ústredný orgán štátnej správy, ktorého je hovorcom, nie Slovenská republika. “ Táto právna veta bola schválená na uverejnenie v Zbierke stanovísk Najvyššieho súdu a rozhodnutí súdov Slovenskej republiky (R 75/2015).

${ }^{12}$ Rozsudok Najvyššieho súdu Slovenskej republiky sp. zn. 7 Cdo 126/2013 z 30. 9. 2014 (R 75/2015), ktorým bolo zamietnuté dovolanie proti rozsudku Krajského súdu v Prešove sp. zn. 12 Co 104/2012 z 28. 2. 2013, ktorým bol zmenený rozsudok Okresného súdu Prešov sp. zn. 28C 223/2009-166 z 24. 11. 2010 tak, že žaloba bola zamietnutá. 
Najvyšší súd v odôvodnení rozhodnutia najprv poukázal na procesné ustanovenia upravujúce, kto je pred súdom oprávnený konat’ za štát (v tom čase $\S 21$ ods. 4 O. s. p., dnes obdobne $\S 73$ CSP). Konštatoval, že štát v súdnom konaní vystupuje spravidla v prípadoch, ktoré sa týkajú práv a povinností vyplývajúcich zo správy majetku štátu a vo veciach týkajúcich sa realizácie mocenských funkcií štátu. Jeho postavenie sa pritom rozlišuje podl'a toho, či výkon týchto práv a povinností vykonáva sám vo vlastnom mene, alebo ich výkonom na základe právnej úpravy poveril iné subjekty, ktoré výkon práv a povinností realizujú vo vlastnom mene. To je dôležité pre určenie vecnej aktívnej a pasívnej legitimácie. Najvyšší súd poukázal na právnu vetu svojho rozsudku sp. zn. 2 Cdo 11/2005 (vo veci aktívnej legitimácie pri správe majetku štátu), podl’a ktorej štát ako spôsobilého účastníka konania nemožno zamieňat' s jeho rozpočtovými organizáciami, ktoré majú vlastnú právnu subjektivitu a vystupujú v právnych vzt’ahoch vo svojom mene. Konštatoval, že ministerstvo vnútra je ústredným orgánom štátnej správy pre Policajný zbor, samo je právnickou osobou a môže vystupovat' pred súdom. Takéto jeho postavenie nemožno zamieňat' s postavením vo veciach, v ktorých vystupuje ako orgán štátu v rozsahu pôsobnosti stanovenej osobitnými predpismi, a z hl'adiska predmetu tohto konania nemožno teda zamieňat' jeho postavenie s postavením Ministerstva vnútra Slovenskej republiky ako zástupcu štátu v súdnom konaní. Nositel'om povinností vyplývajúcich zo služobného pomeru hovorcu Prezídia Policajného zboru nie je Slovenská republika: „Hovorca Prezídia Policajného zboru v tejto veci poskytol informácie médiám nie ako zástupca štátu (nešlo o priame zastupovanie štátu), ale titulom výkonu služobného pomeru vo vzt'ahu priamej podriadenosti ministrovi-Ministerstvo vnútra SR. Preto aj za (prípadné) porušenie povinností vyplývajúcich zo služobného pomeru - hovorcu PZ - je daná priama zodpovednost' MV SR, nie Slovenskej republiky, za ktorú pred súdom koná príslušný štátny orgán. Preto v danom prípade nie je Slovenská republika nositel'om zodpovednosti za konanie hovorcu PZ, pretože za jeho činnost’ zodpovedá priamo MV SR ako samostatný subjekt práv a povinností stanovených zákonom."

\section{b/ Zodpovednost' za výroky ministra ${ }^{13}$}

Aj v d'alšej veci rozhodovanej Najvyšším súdom Slovenskej republiky bol za pasívne vecne legitimovaný subjekt považovaný štátny orgán, a nie štát. Žalobca (sudca) sa tu domáhal ospravedlnenia a náhrady nemajetkovej ujmy v peniazoch za to, že minister (spravodlivosti) na tlačovej besede o žalobcovi uviedol, že v dvoch prípadoch jeho postup v súdnom konaní vzbudzuje pochybnosti o jeho svedomitosti, nestrannosti a nezaujatosti. Za žalovaného označil štát (Slovenskú republiku - Ministerstvo spravodlivosti Slovenskej republiky). Okresný súd žalobe vyhovel v časti ospravedlnenia i náhrady nemajetkovej ujmy v peniazoch.

${ }^{13}$ Uznesenie Najvyššieho súdu Slovenskej republiky sp. zn. 3 Cdo 131/2017 zo 17. 10. 2018 (neskôr zrušené nálezom Ústavného súdu Slovenskej republiky sp. zn. II. ÚS 261/2019-48 z 27. 8. 2020), ktorým bol zrušený rozsudok Krajského súdu v Bratislave sp. zn. 6 Co 189/2015 z 15. 2. 2017 potvrdzujúci vyhovujúce rozhodnutie Okresného súdu Bratislava III. sp. zn. 19 C 17/2008 z 27. 11. 2014. 
Odvolací súd rozhodnutie ako vecne správne potvrdil. K námietke žalovaného, že vo veci nie je pasívne vecne legitimovaný štát, ale ministerstvo spravodlivosti, uviedol: „(...) žalobca uplatnil na súde nárok na ochranu osobnosti z dôvodu neoprávneného zásahu spôsobeného nepravdivou informáciou poskytnutou médiám ministrom spravodlivosti. Podl'a názoru odvolacieho súdu minister spravodlivosti vystupoval ako zástupca štátu, nebol z pozície svojej funkcie podriadený, resp. zamestnancom MS SR, ale stál na jeho čele ako člen vlády SR. Za jeho činnost’ preto nezodpovedá MS SR. Za prípadné porušenie povinností samotným ministrom spravodlivosti je daná priama zodpovednost' štátu a nie MS SR. V prípade, ak pri výkone verejnej moci dôjde k zásahu do osobnostných práv fyzickej osoby, pri riešení otázky pasívnej legitimácie treba postupovat analogicky podl’a zák. č. 514/2003 Z. z., t. j. pri vzniku nemajetkovej ujmy podl'a § 13 OZ je pasívne legitimovaný štát, v ktorého mene koná MS SR.“

Najvyšší súd Slovenskej republiky na dovolanie žalovaného rozsudok odvolacieho súdu zrušil a vec vrátil na d’alšie konanie. Konštatoval, že rozhodnutie odvolacieho súdu záviselo od vyriešenia právnej otázky, a to „otázky pasívnej vecnej legitimácie subjektu $v$ konaní o ochranu osobnosti za neoprávnený zásah do osobnostných práv zo strany osoby reprezentujúcej orgán verejnej moci pri výkone tejto moci“, ktorú odvolací súd vyriešil tak, že sa odklonil od ustálenej rozhodovacej praxe dovolacieho súdu. Tá podl'a dovolacieho súdu uzavrela, že pasívne vecne legitimovaným je v týchto prípadoch štátny orgán, a nie štát, pričom odkázal na rozhodnutia dovolacieho súdu sp. zn. 3 Cdo 176/2012 z 26. 9.2013 (R 127/2014), sp. zn. 3 Cdo 201/2007 z 30. 7.2008 a sp. zn. 6 Cdo 149/2011 z 26. 9. $2012^{14}$.

Vo vzt'ahu k rozhodnutiu R 127/2014 dovolací súd uviedol, že tu bol vyslovený „,pri riešeni otázky pasívnej vecnej legitimácie v konani o ochrane osobnosti záver, podla ktorého v občianskoprávnych vzt'ahoch sa uplatňuje zásada, v zmysle ktorej za škodu (ujmu) zodpovedá ten, kto ju spôsobil; v prípade škody spôsobenej právnickou osobou ide o činnost' tých osôb, ktoré právnická osoba na túto činnost' použila (\$ 420 aj § 11 a nasl. OZ). $Z$ tejto zásady existujú v občianskoprávnych vzt’ahoch výnimky len v prípadoch výslovne uvedených v zákone (\$ 422 a § 427 OZ). Výnimka zo zásady, že za škodu zodpovedá ten, kto ju spôsobil, vyplýva tiež zo zák. č. 58/1969 Zb. o zodpovednosti za škodu spôsobenú rozhodnutím orgánu štátu alebojeho nesprávnym úradným postupom ako aj zo zák. č. 514/2003 Z. z. v ustanoveni § 1 ods. 1, podl'a ktorého za škodu spôsobenú niektorým orgánom verejnej moci nezodpovedá orgán, ale štát. V pôsobnosti týchto zákonov to teda znamená, že bez ohl'adu na skutočnost', ktorý štátny orgán (orgán verejnej moci) škodu spôsobil, subjektom zodpovedným za škodu a pasívne vecne legitimovaným v konaní o náhradu škody je štát. To ale neplatív odlišných právnych vzt'ahoch a v pôsobnosti iných zákonov; neplatí to medzi iným ani vtedy, ked' ide o ochranu osobnosti (\$ 11 OZ) a pôvodcom zásahu je právnická osoba - štátny orgán, konkrétnym konaním ktorého malo dôjst’ k zásahu do osobnosti. “15

${ }^{14}$ Tieto rozhodnutia riešili súvisiace otázky, no ani v jednom nešlo o zodpovednost' za výroky hovorcu či ústavného činitel'a.

${ }^{15}$ Vo veci R 127/2014 išlo o náhradu nemajetkovej ujmy, ktorá mala vzniknút' žalobcovi v dôsledku obsahu odôvodnenia rozhodnutia (vydaného NBS) za účinnosti zák. č. 58/1969 Zb. Okresný súd zaviazal na náhradu nemajetkovej ujmy Slovenskú republiku a voči NBS žalobu zamietol. Rozhodnutie právne odôvodnil § 13 OZ. Odvolací súd zmenil jeho rozhodnutie tak, že čiastočne vyhovel žalobe voči NBS a vo vzt’ahu k Sloven- 
V tejto súvislosti dovolací súd spomenul aj uznesenie Ústavného súdu Slovenskej republiky sp. zn. I. ÚS 137/07. ${ }^{16}$

Ak Najvyšší súd odkázal na rozhodnutie sp. zn. 3 Cdo 201/2007 z 30. 7. 2008, jeho obsah zhrnul tak, že v tejto veci bolo konštatované, že „,k zásahu do osobnostných práv žalobcu došlo postupom orgánov činných v trestnom konaní (obvinením a vzatím do väzby), ako aj informovaním verejnosti o priebehu trestného stíhania žalobcu. V danom prípade však žalovaná (Slovenská republika - Ministerstvo spravodlivosti Slovenskej republiky) predmetné rozhodnutia nevydala ani verejnost'o trestnom stihani neinformovala. Z uvedeného dôvodu ju preto nebolo možné považovat' za subjekt zásahu. Z hl'adiska určenia subjektu zásahu do osobnostných práv nemožno štát, ani ústredný orgán štátnej správy pre súdy a väzenstvo stotožňovat's odlišnými subjektmi (policajnými orgánmi, prokuratúrou, súdmi, médiami a pod.), ktoré majú samostatnú právnu subjektivitu a nesú vlastnú zodpovednost' za prípadné zásahy do osobnostných práv žalobcu. ${ }^{{ }^{617}}$

O rozhodnutí vo veci sp. zn. 6 Cdo 149/2011 z 26. 9. 2012 dovolací súd uviedol, že tu konštatoval, že „,kým pasívne legitimovaným subjektom, voči ktorému je uplatňovaný nárok na náhradu škody spôsobenej orgánmi verejnej moci pri výkone verejnej moci môže byt’ v zmysle zák. č. 514/2003 Z. z. len štát, pasívne legitimovaným subjektom, voči

skej republike žalobu zamietol pre nedostatok pasívnej vecnej legitimácie. Právna veta R 127/2014 v zbierke rieši otázku zodpovednosti za odôvodnenie rozhodnutia.

${ }^{16}$ Uznesením sp. zn. I. ÚS 137/07 z 23. 8. 2007 bola odmietnutá ústavná st'ažnost' st’ažovatel'ky, ktorá videla porušenie svojich základných práv v tom, že hoci v jej veci došlo k nesprávnemu úradnému postupu súdu ešte za účinnosti zák. č. 58/1969 Zb., ktorý náhradu nemajetkovej ujmy nepoznal, mali súdy jej žalobu o náhradu nemajetkovej ujmy, ktorá jej vznikla v dôsledku nesprávneho úradného postupu, posúdit’ podl'a § 11 a nasl. OZ, čo však neurobili. Nesprávnym úradným postupom bolo vyznačenie doložky o právoplatnosti na platobný rozkaz napriek podaniu riadneho odporu. Ústavný súd nepovažoval závery všeobecných súdov o zamietnutí žaloby o náhradu nemajetkovej ujmy st’ažovatel'ky v dôsledku toho, že zák. č. 58/1969 Zb. tento nárok nepoznal, za arbitrárne. Dodal, že aj tento „,zákon patrí medzi výnimky zo všeobecnej zásady, podl'a ktorej subjekt práva zodpovedá za škodu, resp. ujmu, ktorú spôsobil. Tento zákon totiž v ustanoveni § 1 ods. 1 zakotvuje, že za škodu spôsobenú niektorým štátnym orgánom nezodpovedá štátny orgán, ale sám štát. Pritom je zrejmé, že štátny orgán a štát sú odlišnými subjektmi práva, teda odlišnými právnickými osobami. Znamená to, že bez ohl'adu na skutočnost', ktorý štátny orgán škodu spôsobil, zodpovedným (vecne pasívne legitimovaným) je štát. Túto výnimku zo zásady o zodpovednosti za škodu však možno uplatnit’ len v medziach pôsobnosti zákona o zodpovednosti štátu, teda iba na prípady, v ktorých vznikla škoda v zmysle jej definície uvedenej v rozsudku krajského súdu. Preto pokial' by sa žaloba st’ažovatel'ky mala právne posúdit' podl'a § 11 a nasl. Občianskeho zákonnika (ako to žiada st’ažovatel'ka), podl'a všetkého by žaloba smerujúca proti štátu musela byt' zamietnutá pre nedostatok jeho vecnej pasivnej legitimácie. “ Inak povedané, ak zák. č. 58/1969 Zb. náhradu nemajetkovej ujmy nepoznal a poznal iba nárok na náhradu škody, potom štát mohol byt’ pasívne legitimovaným iba vo vzt’ahu k žalobám o náhradu škody, a preto by musela byt' voči štátu zamietnutá žaloba o náhradu nemajetkovej ujmy.

${ }^{17} \mathrm{~V}$ tejto veci bol žalobca obvinený, mesiac bol vo väzbe, následne bolo jeho trestné stíhanie zastavené, no o jeho trestnom stíhaní informovali médiá predstavitelia Ministerstva vnútra Slovenskej republiky (za účinnosti zák. č. 58/1969 Zb.). Žalobou požadoval náhradu škody a nemajetkovej ujmy, ktoré mu vznikli nezákonným vznesením obvinenia, väzbou, stíhaním a poškodením cti. Žalovaným bola Slovenská republika. V časti o náhradu škody bolo žalobe právoplatne vyhovené, v časti náhrady nemajetkovej ujmy dovolací súd zrušil vyhovujúce rozhodnutia okresného a krajského súdu. Následne bola žaloba o náhradu nemajetkovej ujmy zamietnutá s odôvodnením, že nejde o neoprávnený zásah podl’a $§ 11$ a nasl. OZ, pretože orgány činné v trestnom konaní postupovali pri vznesení obvinenia a väzbe v súlade s právnym poriadkom. Dovolanie st'ažovatel'a bolo zamietnuté, pretože pôvodcom zásahu do osobnosti žalobcu nebola Slovenská republika, ale mohli ním byt' (ak by išlo o zásah neoprávnený) iba jej orgány so samostatnou právnou subjektivitou. 
ktorému je uplatňovaný nárok na ochranu osobnosti podl'a § 11 a nasl. OZ, je pôvodca neoprávneného zásahu do osobnostných práv. "18

Ďalej pre úplnost' dovolací súd dodal, že v danom prípade sa nemožno stotožnit’ ani s názorom odvolacieho súdu súvisiacim s použitím analógie legis zákona o zodpovednosti za škodu spôsobenú výkonom verejnej moci, ${ }^{19}$ čo odôvodnil tým, že ,,nároky vyplývajúce z neoprávnených zásahov do práva na ochranu osobnosti sú podl'a platnej právnej úpravy pojmovo odlišné od nárokov na náhradu škody. Zákon č. 514/2003 Z. z. síce v ustanovení § 17 ods. 2 predpokladá, že pri odškodňovani môže byt' poskytnutá náhrada nie len za škodu a ušlý zisk, ale aj za spôsobenú nemajetkovú ujmu, platná právna úprava však rozlišuje medzi právom na ochranu osobnosti (\$11 a nasl. OZ) a právom na náhradu škody. Právo na ochranu osobnosti predstavuje nemajetkové právo rýdzo osobnej povahy, ktoré je úzko späté s osobnostou človeka a jej prejavmi, právo na náhradu škody je na rozdiel od tohto právo majetkovej povahy, ktoré môže patrit’ tak fyzickej ako aj právnickej osobe a nemá absolútnu, ale iba relatívnu povahu. Ide preto o dve celkom samostatné práva, ktoré sú podmienené rôznou sférou ochrany zabezpečovanej OZ."20

${ }^{18} \mathrm{~V}$ tejto veci sa domáhal žalobca ospravedlnenia a náhrady nemajetkovej ujmy tvrdiac, že v odôvodnení právoplatného rozsudku vydaného v civilnej veci, v ktorej nebol účastníkom, boli o ňom uvedené nepravdy. Za žalovaného v 1/ rade označil Slovenskú republiku zastúpenú Ministerstvom spravodlivosti Slovenskej republiky a za žalovaných v 2/ - 4/ rade Slovenskú republiku zastúpenú jednotlivými sudcami, ktorí vo veci rozhodovali. Okresný súd vec posudzoval podl’a zák. č. 514/2003 Z. z. Žalobu zamietol jednak pre nedostatok aktívnej legitimácie žalobcu, pretože tento nebol účastníkom konania, v ktorom bol rozsudok vydaný, d'alej preto, že žalobca nepreukázal predpoklady vzniku zodpovednosti za nemajetkovú ujmu a nakoniec preto, že žalovaní v $2 /$ - 4/ rade neboli vo veci pasívne legitimovaní. Odvolací súd jeho rozhodnutie potvrdil. Dovolací súd oba rozsudky zrušil a vec vrátil na d’alšie konanie, pretože žalovanými v 1/ - 4/ bola označená Slovenská republika viackrát, hoci zastúpená rôznymi subjektmi, pričom štát nemôže sám so sebou tvorit’ spoločenstvo účastníkov. K citovanej časti odôvodnenia však dodal aj to, že ,pokial' by $k$ zásahu do osobnostných práv malo dôjst' čast'ou odôvodnenia rozhodnutia súdu, pasívne legitimovaným subjektom v konaní o ochranu osobnosti je tiež štát. Rozhodnutie súdu ako orgánu verejnej moci je totiž výsledkom výkonu súdnej moci-súdnictva, t.j. výkonu verejnej moci. Na tomto rozhodnutí sa podiel'ajú sudcovia ako predstavitelia súdnej moci, ktorí sú podl'a § 25 ods. 1 zák. č. 385/2000 Z. z. o sudcoch a prísediacich v osobitnom vzt'ahu $k$ štátu. Ak pasívne legitimovaným subjektom v konaní o náhradu škody spôsobenej pri výkone verejnej moci orgánmi verejnej moci je v zmysle zák. č. 514/2003 Z. z. štát, potom analogicky je štát pasivvne legitimovaným aj v konaní o ochranu osobnosti za neoprávnený zásah do osobnostných práv orgánmi verejnej moci pri výkone tejto moci. Rovnako analogicky koná za štát Ministerstvo spravodlivosti Slovenskej republiky. “

${ }^{19}$ Hoci čiastočne opačný záver o prípustnosti analógie zák. č. 514/2003 Z. z. pri určení pasívne legitimovaného subjektu zaujal Najvyšší súd v už prv citovanom rozhodnutí sp. zn. 6 Cdo 149/2011.

${ }^{20} \mathrm{~V}$ tejto súvislosti dovolací súd odkázal aj na svoje rozhodnutie sp. zn. 4 Cdo 168/2009 z 20. 4. 2011. V tejto veci boli žalobcami pozostalí po obeti dopravnej nehody, žalovaným v 1/ rade bola komerčná poist’ovňa, u ktorej bolo vozidlo škodcu povinne zmluvne poistené, žalovaným v 2/ rade prevádzatel' vozidla a predmetom konania náhrada nemajetkovej ujmy v peniazoch podl'a § $13 \mathrm{OZ}$. Okresný i krajský súd žalobe vyhoveli, ked' zodpovednost' za nemajetkovú ujmu prevádzatel'a založili na $§ 427 \mathrm{OZ}$, zodpovednost' žalovanej poist'ovne na ustanoveniach zákona o povinnom zmluvnom poistení, ktoré vykladali tak, že škodou sa rozumie i nemajetková ujma. Dovolací súd rozhodnutie krajského súdu zrušil ako nedostatočne odôvodnené a vec mu vrátil na d’alšie konanie; nad rámec toho zaujal i právny názor, podl'a ktorého ,povinnost' poskytnút' zadost'učinenie podl'a § 13 OZ je subjektívne spätá s tým, kto sa zásahu do práv iného dopustil. Jedná sa o výlučnú osobitnú povinnost' tohto subjektu, ktorá neprechádza na d’alšiu osobu. V konaní o náhradu nemajetkovej ujmy spôsobenej zásahom do osobnostných práv, je v zmysle § 11 a nasl. OZ nositelom hmotnoprávnej povinnosti ten subjekt, ktorý neoprávnený zásah do osobnostných práv spôsobil." Dovolací súd vykladal aj pojem škoda v zákone o povinnom zmluv- 
Pre úplnost' je potrebné uviest', že toto rozhodnutie dovolacieho súdu bolo neskôr zrušené nálezom Ústavného súdu Slovenskej republiky sp. zn. II. ÚS 261/2019-48 z 27. 8. 2020 a vec bola vrátená dovolaciemu súdu na d’alšie konanie. Ústavný súd však postupoval zdržanlivo a k posúdeniu pasívnej vecnej legitimácie iba konštatoval, že okresný a krajský súd prijali v otázke pasívnej legitimácie, jasné a dostatočné závery. Ich úvahy o vecnej pasívnej legitimácii žalovanej sú z pozície ústavného súdu viac akceptovatel’né a tolerovatel'nejšie ako formalistické posúdenie tejto otázky najvyšším súdom opierajúce sa o jeho dve, resp. tri rozhodnutia“. Rozhodnutie dovolacieho súdu označil za ,prekvapujúce, formalistické“, ked' navyše ,,pochybenia štátnych orgánov by v zásade nemali ist' na úkor nositel'ov l'udských práv". O porušení práva st'ažovatel'ky na súdnu ochranu rozhodol s poukazom na potrebu ,,uprednostnit' právnu istotu $v$ záujme ochrany procesných práv budúcich žalobcov proti štátnym orgánom v sporoch o ochranu osobnosti “.

Závery vyslovené v rozhodnutí Najvyššieho súdu Slovenskej republiky sp. zn. 3 Cdo 131/2017 z 17. 10. 2018 a v rozhodnutiach v n̆om citovaných neskôr doslovne prevzalo i d’alšie rozhodnutie Najvyššieho súdu Slovenskej republiky. ${ }^{21}$ Následne boli v inej veci tieto právne závery rozvinuté nižšími súdmi do kategorického konštatovania, podl'a ktorého „Slovenská republika nemôže byt pasívne legitimovaná v konaní o ochranu osobnosti “. 22

\section{O súkromnoprávnej a verejnoprávnej zodpovednosti štátu a štátnych inštitúcií}

Tieto rozhodnutia Najvyššieho súdu Slovenskej republiky nastol’ujú viaceré otázky výkladu právnej úpravy zodpovednosti za škodu a nemajetkovú ujmu podl'a Občianskeho zákonníka, zákona č. 514/2003 Z. z. a d’alších predpisov, vzájomného vzt'ahu týchto noriem, ale aj zodpovednosti za konanie osôb použitých a excesu z tejto zodpovednosti.

\subsection{Zodpovednost’ za škodu a nemajetkovú ujmu spôsobenú mimo výkonu verejnej moci podl'a predpisov súkromného práva}

Súkromnoprávna zodpovednost' štátu, resp. jeho inštitúcií je založená normami súkromného práva a je pre ňu charakteristické, že nejde o zodpovednost' za výkon verejnej

nom poistení, a to tak, že tento pojem nezahŕňa náhradu nemajetkovej ujmy v peniazoch. Ako je známe, tento názor bol neskôr prekonaný a presadil sa názor opačný (napr. uznesenie Ústavného súdu Slovenskej republiky sp. zn. III. ÚS 666/2016 z 11. októbra 2016 atd'.)

${ }^{21}$ Uznesenie Najvyššieho súdu Slovenskej republiky sp. zn. 5 Cdo 132/2018 z 30. 5. 2019. Žalobca sa domáhal určenia, že konaním žalovaných došlo k porušeniu § 11 a nasl. OZ. Za žalovaných označil 1/ Slovenskú republiku - Ministerstvo spravodlivosti Slovenskej republiky, 2/ Slovenskú republiku - Ministerstvo vnútra Slovenskej republiky a 3/ Slovenskú republiku - Generálnu prokuratúru. Išlo o trestné stíhanie, ktoré sa skončilo oslobodením spod obžaloby.

${ }^{22}$ Rozsudok Okresného súdu Košice I. č. k. 12 C 68/2013-307 z 27. 1.2017 potvrdený rozsudkom Krajského súdu v Košiciach sp. zn. 5 Co 248/2017 z 12. 12. 2017. Tento názor má zrejme pôvod v argumentácii českého ministerstva spravodlivosti (rozsudky Najvyššieho súdu Českej republiky sp. zn. 30 Cdo 1638/2007 z 31. 1. 2008, sp. zn. 28 Cdo 2081/2011 z 18. 10. 2011). 
moci. Pri súkromnoprávnej zodpovednosti štátu za škodu a nemajetkovú ujmu sú predpoklady jej vzniku stanovené vo všeobecných hmotnoprávnych predpisoch, najmä v Občianskom zákonníku. O výkon verejnej moci nepôjde tam, kde štát nevystupuje v tzv. vrchnostenskej pozícii, ale vstupuje do právnych vzt’ahov ako ich účastník rovný s ostatnými účastníkmi, teda najmä ako subjekt občianskoprávnych vzt’ahov v zmysle $§ 21$ $\mathrm{OZ},{ }^{23}$ podl'a ktorého, ak je účastníkom občianskoprávnych vzt'ahov štát, je právnickou osobou.

Za škodu spôsobenú porušením právnej povinnosti vyplývajúcej z občianskoprávnych vzt'ahov zodpovedá štát, resp. jeho inštitúcia poverená konat' vo vlastnom mene (napr. nakladat' s majetkom štátu), podl'a všeobecných predpisov rovnako ako za škodu spôsobenú mimo rámec výkonu verejnej moci konaním, s ktorým zákon spája zodpovednost' objektívnu (napr. zodpovednost' za škodu spôsobenú prevádzkou dopravných prostriedkov). Pri zodpovednosti za škodu spôsobenú v prípadoch nakladania so štátnym majetkom, ide najmä o nároky z neplatnosti takýchto zmlúv, či z bezdôvodného obohatenia podl'a občianskeho zákonníka, ale môže íst' aj o zodpovednost' za škodu založenú Obchodným zákonníkom. ${ }^{24}$

Súdna prax riešila v súvislosti so správou majetku štátu (podl'a zák. č. 278/1993 Z. z. o správe majetku štátu) viaceré otázky, napr. či vymáhat' pohl'adávku z bezdôvodného obohatenia vzniknutého neplatnost'ou zmluvy uzatvorenej štátom ako kupujúcim je oprávnený správca alebo štát ${ }^{25}$ alebo otázku, či štátny orgán (ministerstvo) je oprávnený vymáhat' pohl'adávku (náhradu škody od ním splnomocneného advokáta) vlastným menom, alebo či tak mohol urobit' iba štát ako subjekt súkromnoprávneho vzt'ahu. ${ }^{26}$ Práve

${ }^{23}$ VOJTEK, P. Odpovědnost za škodu při výkonu veřejné moci. Komentář. 3. vydání. Praha : C. H. Beck, 2012, s. 8 .

${ }^{24} \mathrm{~K}$ tomu viac: VOJTEK, P. Odpovědnost za škodu při výkonu veřejné moci. Komentár̆. 3. vydání. Praha : C. H. Beck, 2012, s. 8.

${ }^{25}$ Rozsudok Najvyššieho súdu Slovenskej republiky, sp. zn. 2 Cdo 94/02 z 25. 2. 2003 (R 87/2004) konštatoval vo vzt’ahu k správe pohl'adávky štátu, že ,pohl'adávkami štátu sú len také pohl'adávky, z ktorých je štát oprávnený priamo. Správu pohl'adávky štátu vykonáva správca v mene štátu; správca k pohl'adávke štátu nemá žiadne oprávnenie a je len orgánom štátu, ktorý môže pri správe pohl'adávky konat'. Z pohl'adávok, ktoré vznikajú v súvislosti s výkonom správy hmotného majetku štátu, je oprávnený správca."V tejto veci išlo o vydanie bezdôvodného obohatenia, ktoré žalovaní získali úhradou kúpnej ceny z neplatnej zmluvy, ktorú so žalovanými ako predávajúcimi uzatvoril ako kupujúci československý štát - Kancelária Slovenskej národnej rady (súd v inom konaní určil neplatnost’ tejto zmluvy). Žalobkyňou bola Kancelária Slovenskej národnej rady (právnická osoba), ktorú Najvyšší súd považoval v spore za aktívne legitimovanú.

${ }^{26}$ Rozsudok Najvyššieho súdu Slovenskej republiky sp. zn. 2 Cdo 11/2005 z 30. 6. 2005 (ZSP č. 4/2006). V tejto veci žalovalo Ministerstvo financií Slovenskej republiky advokáta o náhradu škody, ktorá mala žalobcovi vzniknút' tým, že advokát ako zástupca žalobcu odpustil druhému žalovanému čast' dlhu bez súhlasu žalobcu. Išlo o pohl'adávku Slovenskej republiky voči inému štátu. Dovolací súd uzavrel, že „Z osobitného postavenia štátu vyplýva, že oprávnenia a povinnosti, ktoré pre neho plynú z jeho vlastníckeho práva k majetku nevykonáva sám, ale prostredníctvom správcov (...) Pritom sa nevylučuje, že správca majetku štátu môže vstúpit’ pri výkone správy do záväzkového vzt’ahu súkromnoprávnej povahy s tretou osobou. V takom prípade vznikom takéhoto záväzkového vzt'ahu štát spravidla práva a povinnosti nenadobúda. Ak preto v súvislosti s porušením takéhoto záväzkového vzt’ahu vznikne pohl'adávka (napr. nesplnený záväzok zo zmluvy, záväzok zo zodpovednosti za škodu) ide o pohl'adávku, z ktorej je oprávnený priamo správca a nie štát. “ Preto potom sám správca môže takýto nárok vo vlastnom mene uplatnit’ aj na súde. Navyše, v tejto veci štát nebol ani účastníkom zmluvného vzt'ahu so žalovaným advokátom, ked' zmluvu s ním uzatvorilo ministerstvo. 
z rozhodnutia vydaného $\mathrm{v}$ tejto veci pochádza i často citovaná právna veta, podl’a ktorej je nevyhnutné dôsledne pri posudzovaní vecnej legitimácie rozlišovat' postavenie štátneho orgánu (rozpočtovej organizácie) ako právnickej osoby v sporoch, v ktorých je zo zákona nositel'om práv a povinností a jeho postavenie $\mathrm{v}$ iných veciach, v ktorých vystupuje len ako organizačná zložka štátu $\mathrm{v}$ jeho mene.

Pri súkromnoprávnej zodpovednosti štátu, resp. štátnych inštitúcií, za nemajetkovú ujmu mimo výkonu verejnej moci, môže íst' o široké spektrum prípadov - od zodpovednosti za nemajetkovú ujmu spôsobenú pri dopravnej nehode až po diskriminačné konanie voči osobe v štátnej službe. V Občianskom zákonníku je to nielen zodpovednost' podl'a $\S 13 \mathrm{OZ}$, ale aj podl'a d'alších noriem občianskeho práva. ${ }^{27}$ Súkromnoprávna zodpovednost' za nemajetkovú ujmu môže vzniknút' aj podl'a zák. č. 513/1991 Zb. Obchodný zákonník ${ }^{28}$ a na základe množstva predpisov upravujúcich nároky z porušenia autorských a priemyselných práv ${ }^{29}$ či predpisov antidiskriminačného práva. ${ }^{30}$

\subsection{Zodpovednost' štátu, resp. jeho inštitúcií za škodu a nemajetkovú ujmu mimo výkonu verejnej moci v osobitne upravených prípadoch}

O zodpovednost' za výkon verejnej moci nejde ani v prípadoch zodpovednosti štátu za škodu upravenú v rôznych osobitných právnych predpisoch. ${ }^{31}$

Ide napríklad o zodpovednost' vyplývajúcu z vlastníctva štátu dial'nic a ciest I. triedy, a to za škodu, ktorá vznikla užívatel’om týchto komunikácií a ktorej príčinou boli závady v zjazdnosti, a to aj s výslovným určením zodpovedného subjektu (správcu). ${ }^{32}$ Ďalej je

${ }^{27}$ Napr. § 19b ods. 2, $3 \mathrm{OZ}$ - neoprávnené použitie názvu právnickej osoby, neoprávnený zásah do dobrej povesti právnickej osoby; $\S 442$ a ods. 1 - porušenie alebo ohrozenie práva duševného vlastníctva.

${ }^{28}$ Napr. $\S 12$ ods. 1,3 - neoprávnené používanie obchodného mena, $\S 53$ - porušenie alebo ohrozenie práv nekalou sút’ažou.

${ }^{29}$ Napr. $\$ 58$ ods. 1 zák. č. 185/2015 Z. z. Autorský zákon - pri neoprávnenom zásahu do práva autora; $§ 8 \mathrm{a}$ zák. č. 506/2009 Z. z. o ochranných známkach - pri neoprávnenom zásahu do výlučných práv majitel'a ochrannej známky; resp. pri neoprávnených zásahoch do práv chránených d’alšími zákonmi: § 75 zák. č. 527/1990 Zb. o vynálezoch, priemyselných vzoroch a zlepšovacích návrhoch, § 19 zák. č. 146/2000 Z. z. o ochrane topografií polovodičových výrobkov, § 32 zák. č. 435/2001 Z. z. o patentoch, dodatkových ochranných osvedčeniach (patentový zákon), § 9 zák. č. 469/2003 Z. z. o označeniach pôvodu výrobkov a zemepisných označeniach výrobkov, atd'.

${ }^{30}$ Najmä zák. č. 365/2004 Z. z. o rovnakom zaobchádzaní v niektorých oblastiach a o ochrane pred diskrimináciou (§ 9 ods. 2), ale aj v osobitných predpisoch naň nadväzujúcich, napr. $\S 13$ ods. 7, § 41 ods. 9 zák. č. 311/2001 Z. z. Zákonník práce, $\$ 5$ ods. 10 zák. č. 552/2003 Z. z. o výkone práce vo verejnom záujme - diskriminácia pri výberovom konaním na obsadenie miesta vedúceho zamestnanca; § 2a ods. 3 zák. č. 73/1998 Z. z. o štátnej službe príslušníkov Policajného zboru, Slovenskej informačnej služby, Zboru väzenskej a justičnej stráže Slovenskej republiky a Železničnej polície, či § 16 ods. 4 zák. č. 315/2001 Z. z. o Hasičskom a záchrannom zbore - pri porušení zásady rovnakého zaobchádzania pri vstupe do štátnej služby alebo počas jej výkonu; $\S 14$ ods. 6 zák. č. 5/2004 Z. z. o službách zamestnanosti - diskriminácia pri realizácii práva na prístup k zamestnaniu bez akýchkol'vek obmedzení v súlade so zásadou rovnakého zaobchádzania atd'.

${ }^{31}$ VOJTEK, P. Odpovědnost za škodu při výkonu veřejné moci. Komentář. 3. vydání. Praha : C. H. Beck, 2012, s. $8-15$.

${ }^{32}$ Podl'a zák. č. 135/1961 Zb. o pozemných komunikáciách (cestný zákon) správcovia dial’nic, ciest a miestnych komunikácií zodpovedajú za škody, ktoré vznikli užívatel'om týchto komunikácii a ktorých príčinou boli závady v zjazdnosti, okrem prípadu, že preukážu, že nebolo v medziach možností tieto závady odstrá- 
osobitne upravená napríklad zodpovednost' za škodu spôsobenú určenými živočíchmi tretím osobám na ich živote, zdraví alebo majetku, opät' aj s presným určením zodpovedného subjektu (orgán ochrany prírody) a v tomto prípade i s odkazom na úpravu zodpovednosti za škodu podl'a Občianskeho zákonníka. ${ }^{33} \mathrm{~V}$ niektorých prípadoch, naopak, úprava zodpovednosti štátu za škodu chýba, hoci by bola namieste (napr. pri škode vzniknutej v príčinnej súvislosti so zásahmi zložiek integrovaného záchranného systému ${ }^{34}$, v dôsledku čoho musí byt' posúdená podl'a všeobecných ustanovení občianskeho práva. Určité špecifiká vykazuje aj zodpovednost' štátu za škodu ním spôsobenú jeho zamestnancom, či už v pomere pracovnoprávnom alebo služobnom, pričom aj tu právna úprava určuje konkrétny zodpovedný subjekt (štátny orgán, ktorý je zamestnávatel'om, služobným úradom atd'.). ${ }^{35}$

\subsection{Zodpovednost’ štátu za škodu a nemajetkovú ujmu pri výkone verejnej moci}

Výkon verejnej moci je spoločenským záujmom, je upravený normami určujúcimi medze aj spôsob jej výkonu. Ked' výkon verejnej moci prekročí tieto hranice, resp. opustí tento spôsob, porušuje nielen právne normy a zákonnost', ale často spôsobuje zúčastneným subjektom i ujmu. Zachovávanie práva a právomoci je nutné požadovat' predovšetkým od štátu a jeho orgánov ${ }^{36}$. Funkciou tejto zodpovednosti je aj prevencia a pre

nit', ani na ne predpísaným spôsobom upozornit' (§ 9a ods. 2). Vo vlastníctve štátu sú dial'nice a cesty I. triedy ( 3 d ods. 1), podl’a § 3d ods. 5 ich správu vykonáva Národná dial'ničná spoločnost' (pri dial'niciach a určených cestách I. triedy) a právnické osoby zriadené na tento účel ministerstvom.

${ }^{33}$ Podl'a $§ 97$ zák. 543/2002 Z. z. o ochrane prírody a krajiny štát zodpovedá za podmienok, v rozsahu a spôsobom ustanoveným týmto zákonom za škodu spôsobenú živočíchmi, ktorých zoznam ustanoví ministerstvo všeobecne záväzným právnym predpisom, na živote a zdraví fyzickej osoby, vybraných domestikovaných živočíchoch atd'. Škodu je povinný nahradit' orgán ochrany prírody, v ktorého územnom obvode ku škode došlo ( $\$ 101$ ods. 3). Podl’a $\S 102$ ods. 1 ak orgán ochrany prírody nezaplatí náhradu škody v termíne a za podmienok uvedených v § 101 ods. 3, môže sa poškodený domáhat’ voči tomuto orgánu priznania škody na súde. Na právne vzt’ahy o náhrade škody spôsobenej určenými živočíchmi sa vzt'ahujú všeobecné ustanovenia o náhrade škody ( $\$ 415-450 \mathrm{OZ}$ ), ak tento zákon neustanovuje inak (§ 102 ods. 2$)$.

${ }^{34}$ Zák č. 129/2002 Z. z. o integrovanom záchrannom systéme takúto úpravu neobsahuje, na rozdiel napríklad od úpravy českej (§ 30 zák. č. 239/2000 Sb. o integrovaném záchranném systému).

${ }^{35}$ Ustanovenia zák. č. 552/2003 Z. z. o výkone práce vo verejnom záujme sa vzt’ahujú aj na vzt’ahy zamestnancov k zamestnávatel'om, ktorými sú štátne orgány (§ 1 ods. 2); podl'a zák. č. 55/2017 Z. z. o štátnej službe sa štátna služba vykonáva v štátnozamestnaneckom pomere k štátu (§ 1 ods. 2); osobitne zákon o štátnej službe v súvislosti s náhradou škody upravuje napr. jednorazové mimoriadne odškodnenie štátneho zamestnanca pri škode na zdraví alebo smrti (§ 151). Zák. č. 73/1998 Z. z. o štátnej službe príslušníkov Policajného zboru, Slovenskej informačnej služby, Zboru väzenskej a justičnej stráže a Železničnej polície upravuje zodpovednost' služobného úradu za škodu pri služobných úrazoch a chorobách z povolania (\$ 174), za škodu na odložených veciach (§ 185). Podobne zodpovedá služobný úrad za škodu aj colníkovi (§ 164 - 179 zák. č. 200/1998 o štátnej službe colníkov, hasičovi (§ 134 - 136 zák. č. 315/2001 Z. z. o Hasičskom a záchrannom zbore). Vo vzt’ahu k sudcom podl'a $§ 103$ ods. 1 zákona č. 385/2000 Z. z. o sudcoch a prísediacich štát zodpovedá sudcovi za škodu, ktorá vznikla sudcovi pri výkone funkcie alebo v súvislosti s ňou. Štát zodpovedá aj za škodu, ktorá vznikla sudcovi a jeho rodinným príslušníkom pre výkon funkcie sudcu (§ 106 ods. 1), d’alej napr. aj za škodu na odložených veciach, pri úrazoch a chorobách z povolania $(\S 108-109)$ atd'.

${ }^{36}$ LUBY, S. Prevencia a zodpovednost'v občianskom práve. Zv. II. Bratislava : Vydavatel'stvo SAV, 1958, s. 293. 
poškodených je táto zodpovednost' zárukou reparácie. Ide o zodpovednost' objektívnu a absolútnu.

Subjektmi tohto zodpovednostného vzt'ahu je okrem poškodeného a škodcu aj subjekt za škodcu zodpovedajúci. Nesprávnost' výkonu úradnej právomoci musí spočívat' v protiprávnosti, pričom poškodenému štát zodpovedá objektívne, bez zist'ovania zavinenia priameho škodcu; keby sa zavinenie škodcu prezumovalo, viedlo by to k predlžovaniu konania o náhradu škody pokusmi o preukázanie exkulpačných dôvodov. ${ }^{37}$

Právo na náhradu škody spôsobenej výkonom verejnej moci má pôvod vo verejnom práve a vo verejnoprávnych vzt'ahoch, ide o verejnoprávnu zodpovednost'. ${ }^{38}$ Pri verejnoprávnej zodpovednosti štátu za škodu a nemajetkovú ujmu je rozhodujúce, či vznikla ako následok výkonu verejnej moci, za ktorý štát zodpovedá v celom rozsahu. Ak to tak je, je potrebné zodpovednostný vzt'ah posúdit' podl'a špeciálnej právnej úpravy zákona o zodpovednosti za škodu. Môže íst' bud' o škodu (nemajetkovú ujmu) spôsobenú nezákonným rozhodnutím, alebo nesprávnym úradným postupom.

Táto zodpovednost' je upravená v zákone č. 514/2003 Z. z., ktorý upravuje (okrem iného) aj zodpovednost’ štátu za škodu spôsobenú orgánmi verejnej moci pri výkone verejnej moci (§ 1 písm. a/). Z hl'adiska rozsahu náhrady tento zákon priznáva poškodenému okrem práva na náhradu skutočnej škody a ušlého zisku (§ 17 ods. 1) i právo na náhradu nemajetkovej ujmy v peniazoch za predpokladu, že iba samotné konštatovanie práva nie je dostatočným zadost'učinením vzhl'adom na ujmu spôsobenú nezákonným rozhodnutím alebo nesprávnym úradným postupom, a túto ujmu nie je možné uspokojit' inak (§ 17 ods. 2). Zároveň stanovuje kritériá na určenie výšky nemajetkovej ujmy v peniazoch (§ 17 ods. 3,4$)$.

\subsubsection{Výkon verejnej moci a nesprávny úradný postup}

Zodpovednost' štátu za škodu a nemajetkovú ujmu vzniká podl’a tohto zákona iba v prípade, ak škoda alebo nemajetková ujma vznikla pri výkone verejnej moci. Výkon verejnej moci je rozhodovanie a úradný postup orgánov verejnej moci o právach, právom chránených záujmoch a povinnostiach fyzických osôb alebo právnických osôb (§ 2 písm. a/). Orgánom verejnej moci je (najmä) štátny orgán (§ 2 písm. b/ bod 1). Štát zodpovedá za podmienok ustanovených týmto zákonom okrem iného aj za škodu spôsobenú orgánmi verejnej moci pri výkone verejnej moci nesprávnym úradným postupom (§ 3 ods. 1 písm. d/).

Za nesprávny úradný postup sa považujú nielen nečinnost' orgánu verejnej moci a zbytočné priet’ahy v konaní, ale aj iný nezákonný zásah do práv, právom chránených záujmov fyzických osôb alebo právnických osôb (§ 9 ods. 1 druhá veta). Nesprávny úradný postup zákon vzhl'adom na predpokladanú rôznorodost' (mnohost' foriem) legálne nedefinuje.

\footnotetext{
${ }^{37}$ LUBY, Š. Prevencia a zodpovednost'v občianskom práve. Zv. II. Bratislava : Vydavatel'stvo SAV, 1958, s. 307.

${ }^{38} \mathrm{~K}$ diskusii o povahe nároku na náhradu škody spôsobenej výkonom verejnej moci viac: KOLBA, J., ŠULÁKOVÁ, M. Nemajetková újma zpưsobená protiprávním výkonem veřejné moci. Praha : Leges, 2014, s. 24.
} 
Nesprávnym úradným postupom je každý taký postup orgánu verejnej moci, ktorý pri jej výkone postupuje v rozpore so všeobecne záväznými predpismi, či v rozpore so zásadami jej výkonu ${ }^{39}$. Inými slovami - nesprávnym úradným postupom je porušenie pravidiel predpísaných právnymi normami pre konanie štátneho orgánu pri jeho činnosti a to najmä také, ktoré nevedie k vydaniu rozhodnutia ${ }^{40}$. Nesprávny úradný postup môže byt' predstavovaný akoukol'vek činnost’ou spojenou s výkonom právomocí štátneho orgánu, ak pri nej alebo $\mathrm{v}$ jej dôsledku dôjde $\mathrm{k}$ porušeniu pravidiel predpísaných právnymi normami pre jeho konanie alebo k porušeniu poriadku určeného povahou a funkciou postupu. Aby išlo o postup úradný, musí tak postupovat' osoba, ktorá plní úlohy štátneho orgánu, a tento postup musí slúžit' výkonu štátnej moci ${ }^{41}$.

\subsection{Vzt'ah zodpovednosti štátu podl'a Občianskeho zákonníka, osobitných predpisov a podl'a zákona č. 514/2003 Z. z.}

Zodpovednost' štátu podl'a zák. č. 514/2003 Z. z. je svojou podstatou osobitná a iba podporne možno použit’ ustanovenia Občianskeho zákonníka ${ }^{42}$, ktorý je všeobecnou normou so subsidiárnou pôsobnost'ou. Rovnaký záver platí aj pre osobitné predpisy upravujúce zodpovednost štátu mimo výkonu verejnej moci s tým, že tieto majú prednost' pred ustanoveniami o zodpovednosti podl'a Občianskeho zákonníka, ak obsahujú odlišnú úpravu.

Ked’že zák. č. 514/2003 Z. z. je voči Občianskemu zákonníku predpisom špeciálnym, zvláštna úprava sa uplatní tam, kde špeciálny predpis stanovuje niečo iného oproti úprave všeobecnej, pričom všeobecnú úpravu možno použit’ tam, kde špeciálny predpis jej aplikáciu nevylučuje bud' výslovným zákazom alebo tým, že stanoví niečo iné. Občiansky zákonník sa teda použije napríklad pre všeobecné vymedzenie pojmu škoda a rozsahu jej náhrady, spoluzavinenie poškodeného, či subsidiárne v otázkach premlčania.

Ustanovenia zák. č. 514/2003 Z. z. nepripúšt’ajú, že by štát mohol za škodu spôsobenú pri výkone verejnej moci zodpovedat' podl'a iného zákona, napr. podl'a ustanovení Občianskeho zákonníka o náhrade škody ${ }^{43}$ Obdobne ani nároky na náhradu nemajetkovej ujmy spadajúce pod zákon o zodpovednosti za škodu spôsobenú výkonom verejnej moci nie je možné uplatňovat' z titulu ochrany osobnosti podl'a Občianskeho zákonníka, pretože úprava zodpovednosti štátu v zákone o zodpovednosti za škodu spôsobenú výkonom verejnej moci je zároveň špeciálnou úpravou $\mathrm{v}$ oblasti ochrany osobnosti tam, kde bolo do týchto práv zasiahnuté pri výkone verejnej moci. ${ }^{44}$

${ }^{39}$ Ústavný súd Českej republiky, nález sp. zn. Pl. ÚS 36/08 z 14. 7. 2010.

${ }^{40}$ VOJTEK, P. Odpovědnost za škodu při výkonu veřejné moci. Komentář. 3. vydání. Praha : C. H. Beck, 2012, s. 147.

${ }^{41}$ Tamže, s. 158.

${ }^{42}$ Napr. KIRSTOVÁ, K. - VOJČÍK, P. Občianske právo hmotné. Druhý diel. Košice : Echoservis, 1993, s. 176.

${ }^{43}$ Ustanovenie $\S 420$ OZ možno použit’ iba v prípade, kde štát nevystupuje v tzv. vrchnostenskej pozícii, ale kde vstupuje do právnych vzt’ahov ako ich účastník rovný s ostatnými účastníkmi (rozsudky Najvyššieho súdu Českej republiky sp. zn. 28 Cdo 2081/2011 z 18. 10. 2011, sp. zn. 25 Cdo 3929/2009 z 25. 2. 2010, sp. zn. 28 Cdo $1987 / 2009$ z 3. 3. 2011 atd'.).

${ }^{44}$ Najvyšší súd Českej republiky, rozsudok sp. zn. 30 Cdo 4704/2018 z 23. 6. 2020. 


\subsection{Koncept zodpovednosti za iných a exces}

Koncept zodpovednosti za iných sa vzt'ahuje nielen na zodpovednost' za nespôsobilé osoby, ale aj za osoby použité na plnenie povinností iného subjektu. Hoci prelamuje princíp zodpovednosti za škodu spôsobenú zásadne len vlastným zavinením (subjektívna zodpovednost'), resp. vlastným zapríčinením (objektívna zodpovednost'), jeho existencia je odôvodnená potrebou zabezpečit účinnú nápravu ujmy tam, kde by ju škodca sám nemohol vykonat' a kde je náprava vel'mi naliehavá, ako aj potrebou odpomôct' dôkaznej núdzi, a napokon potrebou pôsobit' zvýšenou mierou v záujme prevencie. Predpokladom zodpovednosti za iného je predovšetkým určitý právny vzt'ah medzi škodcom a osobou, ktorá za neho zodpovedá. Ide tu o zodpovednost významného prevenčného aj reparačného dosahu. ${ }^{45}$ Tento koncept sa uplatňuje pri zodpovednosti za škodu a nemajetkovú ujmu spôsobenú použitými osobami tak súkromnoprávnymi, ako aj verejnoprávnymi subjektmi.

\section{a/ Zodpovednost' súkromnoprávnych subjektov}

Občianskoprávna zodpovednost' za škodu spôsobenú použitou osobou je založená na princípe, podla ktorého je škoda spôsobená (právnickou alebo fyzickou) osobou, ked' bola spôsobená pri jej činnosti tými, ktorých na túto činnost' použila, pričom samy tieto fyzické osoby za škodu takto spôsobenú poškodenému nezodpovedajú, no ich zodpovednost' voči právnickej (fyzickej) osobe, ktorá ich na činnost' použila, stanovená osobitnými predpismi, tým nie je dotknutá ( $\$ 420$ ods. 2 OZ).

Právna teória i súdna prax (slovenská i česká) sa zhodujú $\mathrm{v}$ tom, že ustanovenie $\S 420$ ods. $2 \mathrm{OZ}$ dopadá na prípady, v ktorých konkrétnu činnost', pri ktorej vznikla škoda, nevykonáva právnická (či fyzická osoba) sama, ale prostredníctvom inej osoby, ktorú zamestnáva alebo ktorej prácu pri svojej činnosti využíva. Použitá osoba nevykonáva prácu vlastným menom a na vlastné riziko, ale pre právnickú (fyzickú osobu) osobu podl’a jej pokynov, či príkazov, prípadne v jej záujme. Podstatné je, či konaniu toho, kto škodu spôsobil, nechýbal miestny, časový a vecný vzt’ah k plneniu úloh právnickej (fyzickej) osoby v rámci jej činnosti, teda či nešlo o konanie, ktorým škodca sledoval vlastný záujem - rozhodujúci je vnútorný (účelový) vztah konania, pri ktorom škoda vznikla, k činnosti právnickej (fyzickej) osoby, ktorú vykonáva. ${ }^{46}$ Vecný (vnútorný účelový) vzt’ah je vzt’ah $\mathrm{k}$ činnosti, ktorou bola spôsobená škoda k úlohám organizácie (k pracovným úlohám, $\mathrm{k}$ služobným povinnostiam). ${ }^{47}$ Pri zamestnancovi $\mathrm{v}$ podstate ide o to, či pri činnosti, ktorou bola škoda spôsobená, sledoval zamestnanec z objektívneho i subjektívneho hladiska plnenie pracovných úloh (plnenie služobných povinností) ${ }^{48}$ Pre záver o tom, či zamestnanec plnil pracovné úlohy, nie sú samy osebe významné motív či pohnútka zamestnanca (predpoklady a predstavy, z ktorých konajúci vychádzal), ale predovšetkým to, či z hladiska vecného, miestneho a časového

${ }^{45}$ LUBY, Š. Prevencia a zodpovednost'v občianskom práve. Zv. II. Bratislava : Vydavatel'stvo SAV, 1958, S. 220 .

${ }^{46}$ R 55/1971, Stanovisko občianskoprávneho kolégia NS ČSSR z 18. 11. 1970, Cpj 87/70.

${ }^{47}$ R 55/1971, Stanovisko občianskoprávneho kolégia NS ČSSR z 18. 11. 1970, Cpj 87/70.

${ }^{48}$ R 55/1971, Stanovisko občianskoprávneho kolégia NS ČSSR z 18. 11. 1970, Cpj 87/70. 
ide objektívne o činnost' konanú pre zamestnávatel'a. ${ }^{49} \mathrm{O}$ činnost' konanú pre zamestnávatel'a môže íst' aj vtedy, ked' je vykonávaná hoci aj bez príkazu zamestnávatel'a, iba na základe vlastného rozhodnutia zamestnanca. ${ }^{50}$ Rozhodujúce bez d’alšieho nie je ani to, či bola činnost' vykonávaná v pracovnom čase alebo či škodu spôsobil zamestnanec v stave opitosti, prípadne či jeho konanie je nakoniec posúdené ako trestný čin. ${ }^{51}$

Priama zodpovednost' toho, kto škodu spôsobil, nastáva len v prípade, že jeho konanie, ktorým bola škoda spôsobená, nepatrí do rámca činnosti právnickej (fyzickej) osoby, pre ktorú prácu vykonal (exces).$^{52} \mathrm{Ak}$ konanie použitej osoby, ktorá spôsobila škodu, nemožno považovat' za činnost' právnickej (alebo fyzickej osoby), ide o vybočenie z tejto činnosti a je daná priama zodpovednost' použitej osoby. ${ }^{53}$ Pri posudzovaní vybočenia z plnenia úloh právnickej osoby zo strany tých, ktorí konali ako pracovníci organizácie, je možné k vymedzeniu plnenia úloh organizácie z objektívneho hl'adiska pristupovat' zásadne negatívne (teda, či nešlo o nejaké iné záujmy), ${ }^{54}$ nepostačuje však akákol'vek súvislost' s plnením pracovných úloh (nepriama), ale vyžaduje sa súvislost' priama. ${ }^{55}$

Rovnaký záver platí aj pri zodpovednosti za nemajetkovú ujmu zhodne podl'a právnej teórie ${ }^{56}$ i slovenskej súdnej praxe: „Ak bol neoprávnený zásah do osobnostných práv fyzickej osoby (\$ 11 a nasl. Občianskeho zákonníka) spôsobený niekým, kto bol použitý právnickou osobou na realizáciu činnosti tejto právnickej osoby, považuje sa takýto zásah za zásah spôsobený priamo právnickou osobou. Pre posúdenie, či išlo o takúto činnost' je určujúca existencia miestneho, časového a vecného vzt’ahu k plneniu danej čin-

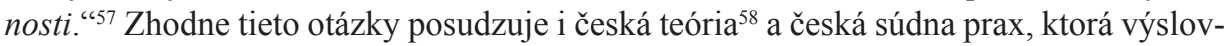
ne používa závery vyslovené skoršími rozhodnutiami súdov v oblasti náhrady škody i pre náhradu nemajetkovej ujmy. ${ }^{59}$ Konštatuje, že pri excese by použitá fyzická osoba bola rovnako priamo postihnutel’ná občianskoprávnymi sankciami podl'a $\S 13 \mathrm{OZ}$.

\footnotetext{
${ }^{49}$ Rozsudok Najvyššieho súdu Českej republiky sp. zn. 21 Cdo 454/2002 zo 14. 1. 2003.

${ }^{50}$ Uznesenie Najvyššieho súdu Českej republiky sp. zn. 25 Cdo 482/2005 z 31. 8. 2005, obdobne Rozsudok Najvyššieho súdu Českej republiky sp. zn. 21 Cdo 1148/2002 z 24. 2. 2003.

${ }^{51}$ R 55/1971, Stanovisko občianskoprávneho kolégia NS ČSSR z 18. 11. 1970, Cpj 87/70.

52 Zhodne: R 57/1961, rozsudok Najvyššieho súdu Českej republiky sp. zn. 25 Cdo 1855/2012 z 25. 6. 2013 atd'.

${ }^{53}$ SVOBODA, J. a kol. Občiansky zákonnik. Komentár. Bratislava : Eurounion, 2004, s. 317.

${ }^{54}$ Rozsudok NS ČSR sp. zn. 1 Cz 7/81 z 31.3.1981; Sborník stanovisek, zpráv o rozhodvání soudů a soudních rozhodnutí Nejvyšších soud ČSSR, ČSR a SSR 1970 - 1983, IV. NS ČSSR, SEVT, Praha, 1986, s. 608.

${ }^{55}$ Najvyšší súd Československej socialistickej republiky, rozsudok sp. zn. 6 Cz 89/68 z 28. 1. 1969 (R 65/1969).

${ }^{56}$ Napr. KNAP, K., ŠVESTKA, J., JEHLIČKA, O., PAVLÍK, P., PLECITÝ, V. Ochrana osobnosti podle občanského práva. Praha : Linde, 1996, s. 139.

${ }^{57}$ Rozsudok Najvyššieho súdu Slovenskej republiky sp. zn. 3 Cdo 228/2012 z 26. 9. 2013 (R 128/2014), doslovne zhodne už prv napr. aj rozsudok Najvyššieho súdu Českej republiky sp. zn. 30 Cdo 73/2003 z 11. 12. 2003.

${ }^{58}$ Napr.: HURDÍK, J., LAVICKÝ, P., TELEC, I. Občanské právo hmotné I. Obecná část, Ochrana osobnosti. Bratislava : BVŠP, 2008, s. 119.

${ }^{59}$ Napr. aj uznesenie Najvyššieho súdu Českej republiky sp. zn. 30 Cdo 4207/2013 z 11. 11. 2015, ktoré dodáva aj to, že pri posudzovaní prípadného excesného konania použitej osoby, ktorým bolo zasiahnuté do osobnosti človeka navyše prichádza do úvahy aj hodnotenie subjektívnych názorov použitej osoby; rozsudok Najvyššieho súdu Českej republiky sp. zn. 30 Cdo 1509/2011 z 3. 10. 2011.
} 


\section{b/ Zodpovednost' verejnoprávnych subjektov}

Právny vzt'ah medzi škodcom a osobou, ktorá za neho zodpovedá môže byt' nie len vzt’ahom pracovnoprávnym založeným Zákonníkom práce, ktorého druhou zmluvnou stranou je zamestnávatel' - subjekt súkromného práva, ale aj iným vzt’ahom s podobnými charakteristikami, v ktorom v postavení „,zamestnávatel'a“ vystupuje subjekt verejnoprávny.

Uvedené závery rovnako ako na použité fyzické osoby v pracovnom pomere so súkromnoprávnymi zamestnávatel'mi dopadajú aj na zamestnancov v pracovnoprávnych vzt’ahoch pri výkone práce vo verejnom záujme $\mathrm{k}$ zamestnávatel’om definovaným $\mathrm{v}$ zákone č. 552/2003 Z. z. o výkone práce vo verejnom záujme (vrátane zamestnávatel’ov, ktorými sú štátne orgány), ale aj na štátnych zamestnancov, teda osoby ktoré vykonávajú štátnu službu $\mathrm{v}$ štátnozamestnaneckom pomere $k$ štátu (§ 1 ods. 2 zákone č. 55/2017 Z. z. o štátnej službe, či d’alšie osobitné zákony upravujúce štátnu službu niektorých skupín štátnych zamestnancov), teda činnosti, ktorými štátny zamestnanec $\mathrm{v}$ rozsahu ustanovenom zákonom plní úlohy štátneho orgánu pri vykonávaní štátnej správy alebo pri vykonávaní štátnych záležitostí v služobnom úrade (§ 6 zákona č. 55/2017 Z. z. o štátnej službe).

Štátna služba príslušníkov ozbrojených zborov je upravená v zákone č. 73/1998 Z. z. o štátnej službe príslušníkov Policajného zboru, Slovenskej informačnej služby, Zboru väzenskej a justičnej stráže Slovenskej republiky a Železničnej polície. Zákon vychádza $\mathrm{z}$ toho, že štátna služba sa vykonáva v služobnom pomere ( $\$ 2$ ods. 2 ) a služobný pomer sa zakladá k štátu (§ 2 ods. 5). Podobne podl’a zákon č. 281/2015 Z. z. o štátnej službe profesionálnych vojakov vykonáva profesionálny vojak štátnu službu v služobnom pomere k Slovenskej republike ( 22 ods. 2). Štátnu službu príslušníkov finančnej správy obdobne upravuje zákon č. 35/2018 Z. z. o finančnej správe, pričom aj táto sa vykonáva v služobnom pomere, ktorý sa zakladá $\mathrm{k}$ štátu (§ 71 ods. 2, 3).

Na postavenie ústavných činitel'ov (vrátane prezidenta, členov vlády, sudcov, verejného ochrancu práv atd'), ktorí sú predstavitel’mi štátnej moci (napr. výkonnej či súdnej), sa nevzt’ahujú zákony o štátnej službe (§ 1 ods. 8 zákona č. 55/2017 Z. z. o štátnej službe), ich postavenie je upravené priamo v Ústave Slovenskej republiky, prípadne v osobitných predpisoch, napr. postavenie sudcov v zákone č. 385/2000 Z. z. o sudcoch a prísediacich, ktoré je definované (aj) tým, že sudca je označený za predstavitel’a súdnej moci (§ 2 ods. 1), ktorú vykonáva v právnom vzt’ahu $\mathrm{k}$ štátu (§ 25 ods. 1).

Ani osoby v týchto vzt’ahoch (v štátnej službe, služobnom pomere či vo verejnej službe a ani ústavní činitelia) nezodpovedajú sami za škodu (nemajetkovú ujmu) spôsobenú pri plnení svojich úloh, ak nejde o exces. Prípadná priama zodpovednost' týchto osôb sa posudzuje podl'a všeobecnej úpravy deliktuálneho práva a môže byt' založená iba v prípade excesu z výkonu ich právomocí. Ak konanie takejto osoby inak reprezentujúcej štát celkom vybočilo z rámca plnenia jej služobných povinností, nejde o výkon verejnej moci. ${ }^{60}$

${ }^{60}$ VOJTEK, P. Odpovédnost za škodu př̌i výkonu veřejné moci. Komentár̆. 3. vydání. Praha : C. H. Beck, 2012, s. 16. 
Prvoradý je aj tu miestny, časový a predovšetkým vecný (vnútorný účelový) vzt'ah k činnosti, pri ktorej bola škoda spôsobená, k plneniu pracovných či služobných úloh, teda k výkonu verejnej moci zo strany orgánu štátu. Pritom je zásadne potrebné vychádzat' z toho, že do rámca činnosti orgánu štátu patrí predovšetkým plnenie povinností a úloh vyplývajúcich z právomoci ustanovenej zákonom a úkony s tým priamo súvisiace, poprípade môže íst' o takú d’alšiu činnost', ktorej nechýba miestny, časový a vecný vzt'ah k činnosti orgánu. Teda aj tam, kde zamestnanec štátu koná pri výkone svojich služobných povinností celkom nevhodným spôsobom, hoci napriek tomu takýmto konaním sleduje plnenie svojich úloh a nie iba svoje osobné alebo iné záujmy, nejde o exces, a to dokonca ani vtedy, ak by jeho konanie naplnilo znaky trestného činu. Zásadne platí, že exces nie je založený len samotným porušením zákona konajúcou použitou osobou. Opačný výklad by viedol k neudržatel’nej praktickej obsoletnosti zákona o zodpovednosti za škodu spôsobenú výkonom verejnej moci, pretože ak by každé nezákonné rozhodnutie či nesprávny úradný postup museli byt' považované za exces, vylučovali by použitie tohoto špeciálneho zákona. ${ }^{61} \mathrm{O}$ exces pôjde, naopak, vtedy, ked’ škoda bola spôsobená pri činnosti, ktorou škodca sledoval vlastné záujmy či potreby, alebo potreby alebo záujmy iných osôb. Aj ked' koná v pracovnom čase či v zdanlivej súvislosti s plnením služobných úkonov, musí byt' zrejmé, že jeho konanie smeruje k naplneniu vlastných ambícií, a nie k výkonu jeho povinnosti. ${ }^{62}$

Zodpovednost' štátu za konanie použitých osôb je v niektorých prípadoch výslovne upravená v osobitných ustanoveniach. Ide najmä o ustanovenia, podla ktorých štát zodpovedá za škodu spôsobenú tretím osobám osobami v štátnej službe či v služobnom pomere (napr. príslušníkmi ozbrojených zborov, profesionálnymi vojakmi ${ }^{63}$ ) v súvislosti s plnením ich úloh ${ }^{64}$.

Hoci predpokladom zodpovednosti za iného je predovšetkým určitý právny vzt’ah medzi škodcom a osobou, ktorá za neho zodpovedá, tento právny vzt'ah nedáva (okrem prípadu, ak tak výslovne stanovuje zákon) odpoved' na otázku, či je zodpovedným subjektom za konanie štátnych zamestnancov štátna inštitúcia (ktorá je služobným úradom), alebo priamo štát (ku ktorému je osoba v služobnom pomere). Aj štátna inštitúcia totiž koná v niektorých prípadoch v mene štátu a v niektorých vo vlastnom mene. Rozhodu-

${ }^{61}$ Rozsudok Najvyššieho súdu Českej republiky sp. zn. 25 Cdo 705/2019 z 23. 3. 2020 (Rč. 97/2021).

${ }^{62}$ VOJTEK, P. Odpovědnost za škodu při výkonu veřejné moci. Komentár̆. 3. vydání. Praha : C. H. Beck, 2012, s. 16.

${ }^{63}$ Napr. podl’a zákona o Policajnom zbore (§ 78 ods. 5) štát zodpovedá za škody spôsobené Policajným zborom alebo policajtmi v súvislosti s plnením ich úloh ustanovených týmto zákonom; podl'a zákona o službe profesionálnych vojakov, štát zodpovedá za škodu, ktorú profesionálny vojak spôsobil tretím osobám pri výkone štátnej služby alebo v priamej súvislosti s jej výkonom (§ 215 ods. 3), či podl’a zákona o finančnej správe štát zodpovedá aj za škody spôsobené príslušníkmi finančnej správy v súvislosti s plnením ich úloh ustanovených zákonom o finančnej správe (§ 314 ods. 2), alebo zák. č. 46/1993 o Slovenskej informačnej službe, podl’a ktorého štát zodpovedá za škody spôsobené SIS, príslušníkom SIS alebo osobou, ktorá im poskytla pomoc v súvislosti s plnením úloh ustanovených týmto zákonom; to neplatí, ak k spôsobeniu škody došlo v dôsledku oprávneného zákroku a protiprávneho konania osoby, ktorej bola spôsobená škoda (§ 19). Náhradu škody poskytuje v zastúpení štátu Slovenská informačná služba (\$20).

${ }^{64}$ Podobne napríklad aj vo vzt’ahu k sudcom zákon výslovne stanovuje, že za škodu spôsobenú rozhodnutím alebo nesprávnym úradným postupom súdu, zodpovedá štát (§ 104 ods. 1 zákona o sudcoch). 
júcou je tak povaha konkrétnej činnosti, na ktorej plnenie bola fyzická osoba použitá, teda v konečnom dôsledku to, či škoda (nemajetková ujma) vznikla pri výkone verejnej moci, alebo mimo neho.

Zodpovednost' štátu za škodu a nemajetkovú ujmu spôsobenú pri výkone verejnej moci podl'a osobitného zákona sa totiž nemôže stat' všeobecnou deliktuálnou zodpovednost'ou podl'a Občianskeho zákonníka iba preto, že fyzická osoba, ktorá škodu (nemajetkovú ujmu) spôsobila, plnila úlohy vyplývajúce pre ňu z právomoci zverenej štátom konkrétnemu štátnemu orgánu (inštitúcii), t. j. formálne plnila jeho úlohy, ak ten konal v mene štátu.

Preto je rozhodujúce, či konanie použitej osoby bolo súčast'ou výkonu verejnej moci, teda v skúmaných prípadoch to, či informovanie o výkone verejnej moci je súčast'ou jej výkonu.

\section{Literatúra}

DRGONEC, J. Ústava Slovenskej republiky. 2. vydanie. Bratislava : Nakladatel'stvo C. H. Beck, 2019, ISBN 978-80-89603-74-9

DRGONEC, J. Metamorfózy náhrady škody spôsobenej nezákonným rozhodnutím a nesprávnym úradným postupom orgánu verejnej moci. Zo súdnej praxe, č. 5/2014, ISSN 1335-177X

GERLOCH, A. Teorie práva. Plzeň : Aleš Čeněk, 2007, ISBN 978-80-7380-023-9

HURDÍK, J. - LAVICKÝ, P. - TELEC, I. Občanské právo hmotné I. Obecná část, Ochrana osobnosti. Bratislava : BVŠP, 2008, ISBN 978-80-89363-06-3

JAKUBÁČ, R. Zákon o zodpovednosti za škodu spôsobenú pri výkone verejnej moci. Komentár. Bratislava : Wolters Kluwer, 2006, ISBN 978-80-8168-462-3

JAKUBÁČ, R. Judikatúra vo veciach zodpovednosti štátu. Bratislava : Iura Edition, 2013, ISBN 978-80-8078676-2

JAKUBÁČ, R. Pasívna vecná legitimácia v sporoch o náhradu škodu spôsobenej nezákonným rozhodnutím orgánu štátu alebo jeho nesprávnym úradným postupom. Justičná revue, č. 3/2013, ISSN 1335-6461

KIRSTOVÁ, K. - VOJČÍK, P. Občianske právo hmotné. Druhý diel. Košice : Echoservis, 1993, ISBN 8088744-00-8

KMEC, J. - KOSAŘ, D. - KRATOCHVÍL, J. - BOBEK, M. Evropská úmluva o lidských právech. Komentáŕr. Praha : C. H. Beck, 2012, ISBN 978-80-7400-365-3

KNAP, K. K problematice odpovědnosti za škodu způsobenou nezákonným rozhodnutím. Socialistická zákonnost, č. $6 / 1965$

KNAP, K. - ŠVESTKA, J. - JEHLIČKA, O. - PAVLÍK, P. - PLECITÝ, V. Ochrana osobnosti podle občanského práva. Praha : Linde, 1996, ISBN 80-7201-029-8

KNAPP, V. Poznámky o tom, za co stát odpovída a za co neodpovída. Právnické štúdie, č. 4/1969, ISSN 05519039

KOLBA, J. - ŠULÁKOVÁ, M. Nemajetková újma zpuisobená protiprávním výkonem veřejné moci. Praha : Leges, 2014, ISBN 978-80-7502-027-7

KRÁLIK, J. Kontrolná moc - systémový prvok verejnej moci vo verejnej správe. Štát a právo, č. 1/2014, ISSN $1339-7753$

LUBY, Š. Prevencia a zodpovednost'v občianskom práve. Zv. II. Bratislava : Vydavatel'stvo SAV, 1958

LUBY, Š. Zodpovednost' za škodu spôsobenú nezákonným rozhodnutím de lege ferenda. Právny obzor, č. 7/1966, ISSN 0032-6984

LUBY, Š. Zodpovednost' za škodu spôsobenú rozhodnutím alebo úradným postupom. Bratislava : Obzor, 1971

ONDRUŠ, R. Přehled judikatury - Odpovédnost státu za nesprávny výkon veřejné moci. Praha : ASPI Publishing, 2004, ISBN 80-7160-002-4 
POSLUCH, M. - CIBULKA, L. Štátne právo slovenskej republiky. Bratislava : PF UK, 1994, ISBN 80-7160002-4

PLANK, K. Zodpovednost’ štátu za nezákonné rozhodnutie. Právny obzor, č. 3/1969, ISSN 0032-6984

PRUSÁK, J. Teória práva. Bratislava : PF UK, 1995, ISBN 80-7160-080-6

Sborník stanovisek, zpráv o rozhodování soudů a soudních rozhodnutí Nejvyšších soudů ČSSR, ČSR a SSR 1970 - 1983, IV. NS ČSSR. Praha : SEVT, 1986

SVOBODA, J. a kol. Občiansky zákonník. Komentár. Bratislava : Eurounion, 2004, ISBN 80-88984-64-5

ŠVESTKA, J. - ČEŠKA, Z. Jak upravit odpovědnost za škodu způsobenou nezákonným rozhodnutím. Právnik, č. 4/1965, ISSN 0231-6625

TITLOVÁ, M. - MEDELSKÝ, J. Zákon o Policajnom zbore. Komentár. Bratislava : Wolters Kluwer, 2017, ISBN 978-80-8168-577-4

VOJTEK, P. Odpovědnost za škodu při výkonu veřejné moci. Komentár̆. 3. vydání. Praha : C. H. Beck, 2012, ISBN 978-7400-427-8

\section{Súdne rozhodnutia}

Ústavný súd Slovenskej republiky, uznesenie sp. zn. I. ÚS 137/07 z 23. 8.2007

Ústavný súd Slovenskej republiky, nález sp. zn. IV. ÚS 107/2010 z 28. 10.2010

Ústavný súd Slovenskej republiky, nález sp. zn. IV. ÚS 284/2012 zo 6. 6. 2013

Ústavný súd Slovenskej republiky, uznesenie sp. zn. III. ÚS 666/2016 z 11. 10. 2016

Ústavný súd Slovenskej republiky, nález sp. zn. II. ÚS 261/2019 z 27. 8.2020

Najvyšší súd Československej socialistickej republiky, rozsudok sp. zn. 6 Cz 192/66 zo 14. 12. 1966 (R 48/1967)

Najvyšší súd Československej socialistickej republiky, rozsudok sp. zn. 6 Cz 89/68 z 28. 1. 1969 (R 65/1969)

Najvyšší súd Československej socialistickej republiky, Stanovisko občianskoprávneho kolégia NS ČSSR z 18. 11. 1970, Cpj 87/70 (R 55/1971)

Najvyšší súd Československej socialistickej republiky, rozsudok sp. zn. 1 Cz 7/81 z 31. 3. 1981

Najvyšší súd Slovenskej republiky, rozsudok sp. zn. 2 Cdo 94/02 z 25. 2.2003 (R 87/2004)

Najvyšší súd Slovenskej republiky, rozsudok sp. zn. 2 Cdo 11/2005 z 30. 6. 2005

Najvyšší súd Slovenskej republiky, rozsudok sp. zn. 4 Cdo 93/2008 z 30. 9. 2008

Najvyšší súd Slovenskej republiky, rozsudok sp. zn. 3 Cdo 201/2007 z 30. 7. 2008

Najvyšší súd Slovenskej republiky, uznesenie sp. zn. 4 Cdo 168/2009 z 20. 4. 2011

Najvyšší súd Slovenskej republiky, uznesenie sp. zn. 6 Cdo 149/2011 z 26. 9. 2012

Najvyšší súd Slovenskej republiky, rozsudok sp. zn. 3 Cdo 176/2012 z 26. 9. 2013 (R 127/2014)

Najvyšší súd Slovenskej republiky, rozsudok sp. zn. 3 Cdo 228/2012 z 26. 9. 2013 (R 128/2014)

Najvyšší súd Slovenskej republiky, rozsudok sp. zn. 7 Cdo 126/2013 z 30. 9. 2014 (R 75/2015)

Najvyšší súd Slovenskej republiky, uznesenie sp. zn. 3 Cdo 131/2017 zo 17. 10. 2018

Najvyšší súd Slovenskej republiky, uznesenie sp. zn. 5 Cdo 132/2018 z 30. 5. 2019

Krajský súd v Bratislave, rozsudok sp. zn. 15 Co 84/2010 zo 14. 9. 2011

Krajský súd v Bratislave, rozsudok sp. zn. 7 Co 207/2010 z 19. 2. 2013

Krajský súd v Bratislave, rozsudok sp. zn. 6 Co 189/2015 z 15. 2. 2017

Krajský súd v Košiciach, rozsudok sp. zn. 5 Co 248/2017 z 12. 12. 2017

Ústavný súd Českej republiky, nález sp. zn. II. ÚS 1191/2008 zo 14. 4. 2009

Ústavný súd Českej republiky, nález sp. zn. Pl. ÚS 36/08 z 8. 7. 2010

Najvyšší súd Českej republiky, rozsudok sp. zn. 21 Cdo 454/2002 zo 14. 1. 2003

Najvyšší súd Českej republiky, rozsudok sp. zn. 21 Cdo 1148/2002 z 24. 2. 2003

Najvyšší súd Českej republiky, uznesenie sp. zn. 25 Cdo 482/2005 z 31. 8. 2005

Najvyšší súd Českej republiky, rozsudok sp. zn. 25 Cdo 3929/2009 z 25. 2. 2010

Najvyšší súd Českej republiky, rozsudok sp. zn.28 Cdo 1987/2009 z 3. 3.2011

Najvyšší súd Českej republiky rozsudok sp. zn. 28 Cdo 2081/2011 z 18. 10. 2011

Najvyšší súd Českej republiky, uznesenie č. k. 30 Cdo 4066/2018 z 29. 4. 2020 (R 96/2021)

Najvyšší súd Českej republiky, rozsudok sp. zn. 30 Cdo 4704/2018 z 23. 6. 2020

Najvyšší súd Českej republiky, rozsudok sp. zn. 25 Cdo 705/2019 z 23. 3.2020 (R 97/2021) 